\title{
Small Firms: Do They Have Better to Go Public?
}

\author{
Achouak Barguelli1 ${ }^{1}$ \\ ${ }^{1}$ University of Tunis El Manar, Tunis, Tunisia \\ Correspondence: Achouak Barguellil, University of Tunis El Manar, Tunis, Tunisia. E-mail: \\ barguellilachouak@yahoo.fr
}

Received: February 11, 2019

Accepted: March 12, 2019

Online Published: March 31, 2019

doi:10.5539/ijef.v11n5p1

URL: https://doi.org/10.5539/ijef.v11n5p1

\begin{abstract}
This paper aims to study the factors that push companies to open its capital to the public. In particular, it examines the impact of a number of factors to explain the under valuation of stock market introduction, particularly performance, debt, liquidity and ownership structure. Our results indicate that large firms are increasingly overvalued. The indebtedness accentuates the problem of overvaluation observed after the IPO. In addition, firms whose capital is concentrated are increasingly under-valued over a long period after the IPO. Our results show that Tunisian companies do not observe the motivation of the search for a better performance after IPO.
\end{abstract}

Keywords: Initial Public Offering (IPO), underpricing, underperformance, extreme bounds analysis

\section{Introduction}

The question of initial public offering (IPO) remains a problematic issue, despite the various models proposed to explain the motives pushing companies to open their capital. In fact, this question was deeply debated in the eighties, especially by Pagano, Panetta and Zingales (1998) for the Italian case, Ritter (1998) for the case of US.

Since the monumental contributions of Scott (1976), Modigliani and Miller (1963), Myers and Majluf (1984), the controversy between the self-financing and debt financing could not be raised and we still be unable to give a universal rule or a critical path describing a situation of optimal financing. The theory of hierarchical financing of Myers and Majluf (1984) states that the most profitable firms are those that have more capital. According to these authors, profitability is found to be inversely correlated with the level of indebtedness. On the other hand, Modigliani and Miller (1963) show that firms most beneficiaries are encouraged to use debt to take maximum advantage of tax benefits. The problem becomes more complicated when adding constraints on the firm's size, the system of governance and the asymmetry information level.

This paper aims to study the motives that make firms go public and to find out causes of abnormal returns preceding this operation. In these conditions, the rest of the paper will be organized as follows: Section 2 provides the literature studying the impact of the decision of going public. Section 3 examines the methodology and framework. Section 4 documents the results and section 5 concludes.

\section{Literature review}

Many studies have focused on the impact of going public on firm's performance and on average investor initial returns. The common results were that firms appear to go public in order to rebalance their accounts after high investment and growth. Results show also that IPOs reduce the cost of credit and increase turnover. However, recent studies have shown that the motivations of a firm to go public have changed. Brau and Fawcett (2006) consider that the most important motivation for going public is no longer minimizing the cost of capital as prevailed during the eighties and the nineties decades, but to create public shares for use in future acquisitions. Loughran, Ritter and Rydqvist (2010) emphasize on the role of the timing of going public and maintain that firms go public in periods of high valuations to avoid excessive underpricing. They have summarized the main studies of average initial return of 47 countries. They've concluded that theses abnormal returns are being reduced between the eighties and the nineties. They explain such dropping by the move of several countries especially in East Asia to reduce regulatory interference and to improve transparency and information efficiency.

Chen and Kim (2004) have studies the performance of Chinese initial public offerings (IPOs). They have worked on the period from mid-1995 to mid-1999 with a sample including 884 companies (both in the A- and B-share 
markets). They conclude that with the exception of earnings related indicators (EPS and ROE) there are no significant changes after an IPO and that financial indicators tend to fall rapidly year on year. They explain this choking result first by the fact that companies tend to submit inflated figures in the financial statements that they are required to provide in order to implement the IPO and secure stock market listing, then by poor corporate governance characteristics of Chinese enterprises.Lowry, Officer and Schwert (2006) have studied variability of IPO initial return during the period 1965-2004. They found that monthly volatility of IPO initial returns is substantial and fluctuates dramatically over time. They explain this volatility by information asymmetry. These results corroborate those of Rock (1986), Beatty and Ritter (1986), and Ritter (1984a) who consider that that uncertainty generates underpricing that compensate costs of becoming informed.

Sohail and Nasr (2007) have studied the performance of 50 IPOs firms quoted on Karachi Stock Exchange from 2000 to 2006 . They found that the average underpricing is $35.66 \%$ determined by ex -ante uncertainty, offer size, market capitalization and oversubscription variables.

In the case of Canada, Jog and Riding (1987), Jog and Srivastava (1994) and Kryzanowski, Lazrak, and Rakita (2006) found and average return of 7,1\%. However, Chen, Choi, and Jiang (2007) have found an initial return of $164,5 \%$ for 1394 Chinese firms during the period 1990 to 2005. This result confirms the conclusion that transparency level is an important criterion of average initial return.

Pagano, Panetta, and Zingales (1998) have found that firms go public not to finance future investment and growth, but to rebalance their accounts after high investment and growth. They point out report that the probability of an IPO is positively impacted by the stock market valuation of firms. They conclude that this positive relationship reflects a growing investment need in sectors with higher growth opportunities. They've also found that company size has a significant correlation with the probability of listing. They've then tried to study causes that make Italian firms delay the decision of going public. The first explanation that the authors propose is that Italian firms need more time to make higher reputation capital due to their rudimentary capital structure making much bigger agency problem. Pagano, Panetta, and Zingales (1998) conclude that going public enables firms to borrow more cheaply. They found that after IPO, the interest rate on short time decrease notably and the number of banks is ready to lend rises sharply.

However, Rydqvist and Hogholm (1995) note that in the case of the US several startup firms go public in order to finance their development, (see Mikkelson et al., 1997). Brau and Fawcett (2006) have interested on the question of why do firms go public. They worked on the base of a survey addressed to 336 chief financial officers. They found that firms go public especially to create public shares for use in future acquisition and that minimizing cost of capital is not among the three most important causes of an IPO. They also conclude that managers are opportunistic because they seek to go public at a time of a high stock price.

Chemmanur and Fulghieri (1999) argue that IPOs extend the ownership structure of the firm. Maksimovic and Pichler (2001) emphasize that firms go public to capture a first mover advantage. They also suggest that going public can increase the reputation of the firm. Boehmer and Ljungqvist (2004) analyzed a sample of 330 German firms from 1984 to 1995 . They found that firms prefer going public when sales and earnings are improved

\section{Data and Methodology}

$$
R A=a_{0}+a_{1} S P+a_{2} \text { Perf }+a_{3} \text { Endet }+a_{4} \text { Liquid }+a_{5} G R+a_{6} \text { Size }+\varepsilon
$$

$\mathrm{Y}=$ abnormal return (dependent variable): this variable is measured by the difference between the observed return and the theoretical return.

The independent variables are:

Ownership structure: measured by the equity participation of the three largest shareholders (Maj1, Maj2, Maj3).

Performance: measured by ROE which is defined by Net Income / Equity.

Indebtedness: measured by debt / total assets.

Liquidity: measured by current assets / current liabilities

The earning management: measured by the discretionary accruals (DA) which is equal to the total accruals (TA) - the non-discretionary accruals (NDA).

The control variables are:

Size;

Crisis. 


$$
N D A=\frac{T A t}{A t-1}=\hat{a} 1\left(\frac{1}{A t-1}\right)+\hat{a} 2\left(\frac{\Delta P E t}{A t-1}\right)+\hat{a} 3\left(\frac{I M M O}{A t-1}\right)
$$

$\mathrm{TA}_{\mathrm{t}}$ : total discretionary accruals in the year $\mathrm{t}$;

$-\mathrm{A}_{\mathrm{t}-1}$ : assets $\mathrm{t}-1$;

- $\triangle \mathrm{OI}$ : change in operating income;

- IMMO: tangible fixed assets.

- First test: test the relevance of abnormal performance during introduction (around the introductory date).

- Second test: test the relevance of abnormal performance for all years.

\section{Model 1}

Model 2

$$
A R_{i t}=c_{0}+\beta_{1} X_{i t}+\varepsilon_{i t}
$$

$$
A R_{i t}=c_{0}+\beta_{1} X_{i t}+\beta_{2} X_{i t} * \text { Crisis }+\varepsilon_{i t}
$$

$\mathrm{AR}$ is abnormal return, $\mathrm{X}$ is variable motivation to go public: size, leverage, ownership, performance, liquidity, earning management

\section{Empirical Results}

\subsection{Size Motivation}

The dependent variable is abnormal return RA, the independents variables are size (log total asset) for model 1 and size and size*crisis (crisis is dummy variable that takes the value one if crisis after 2007 and zero before 2007.

Table 1. Size motivation

\begin{tabular}{lcccc}
\hline & \multicolumn{2}{c}{ The first 3 years after IPO } & \multicolumn{2}{c}{ The first 5 years after IPO } \\
\cline { 2 - 5 } & Model1 & Model2 & Model1 & Model 2 \\
\hline Constant & 5.6939 & 4.967 & $\mathbf{1 6 . 9 8 2 3}^{\boldsymbol{c}}$ & $\mathbf{1 7 . 8 5 1 3}^{\boldsymbol{b}}$ \\
size & -1.1914 & -0.981 & $\mathbf{- 3 . 6 2 0 0 8 ^ { \boldsymbol { a } }}$ & $\mathbf{- 3 . 8 3 2 5}^{\boldsymbol{c}}$ \\
size*crisis $^{*}$ & - & $-\mathbf{0 . 2 5 0 7 ^ { c }}$ & - & .09750 \\
Fisher /wald & $2.201(0.138)$ & $6.11(0.04)$ & $7.84(0.006)$ & $4.03(0.021)$ \\
$\mathrm{R}^{2}$ & 0.0391 & 0.1641 & 0.076 & 0.078 \\
$\mathrm{~N}$ & 72 & 72 & 120 & 120 \\
Chi2(prob>chi2) & $3.33(0.189)$ & $2.77(0.428)$ & $6.14(0.046)$ & $6.40(0.093)$ \\
\hline
\end{tabular}

a, b, c coefficients are significant at the 1,5 , and 10 percent respectively.

Large companies generally have better access to the capital needed to finance their investments. Several studies have shown a negative link between firm size and short-term overvaluation (Ibbotson and al (1994), Carter and al (1998). The size of the firm is associated with negative abnormal returns after the IPO over a period of 5 years. These results mean that large firms are increasingly overvalued. the combined effect of the crisis and size is irrelevant.

\subsection{Leverage Motivation}

Table 2. Leverage motivation

\begin{tabular}{ccccc}
\hline & \multicolumn{2}{c}{ The first 3 years after IPO } & \multicolumn{2}{c}{ The first 5 years after IPO } \\
\cline { 2 - 5 } & Model1 & Model2 & Model 1 & Model 2 \\
\hline Constant & $\mathbf{7 . 4 3 4 5}^{\mathbf{b}}$ & 0.6368 & 0.1647 & 0.1858 \\
debt & $\mathbf{- 1 5 . 3 6 5}^{\mathbf{b}}$ & -0.5314 & -0.0116 & 0.0549 \\
debt*crisis $^{*}$ & - & $\mathbf{2 . 0 4 8}^{\mathbf{c}}$ & - & -0.4542 \\
Fisher /wald & $6.62(0.01)$ & $3.35(0.187)$ & $0.00(0.98)$ & $0.30(0.85)$ \\
$\mathrm{R}^{2}$ & 0.1235 & 0.0725 & 0.0039 & 0.0084 \\
$\mathrm{~N}$ & 72 & 72 & 120 & 120 \\
Chi2(prob>chi2) & $6.14(0.046)$ & $4.85(0.183)$ & $0.83(0.66)$ & $0.78(0.85)$ \\
\hline
\end{tabular}

a, b, c coefficients are significant at the 1,5 , and 10 percent respectively.

Pagans et al. (1998) point out that access to a source of financing other than banks or venture capital is the main advantage of the IPO. Basile (1988) and Pagans et al. (1998) also believe that access to capital markets can 
decrease the cost of credit as a result of bargaining power with banks. The results show that companies newly introduced on the stock market ( 3 years) and which are indebted realize negative abnormal returns. This result confirms the hypothesis that indebtedness accentuates the problem of overvaluation observed after the IPO.

\subsection{Ownership Structure Motivation}

Table 3. The ownership structure motivation

\begin{tabular}{lcccc}
\hline & \multicolumn{2}{c}{ The first 3 years after IPO } & \multicolumn{2}{c}{ The first 5 years after IPO } \\
\cline { 2 - 5 } & Model 1 & Model 2 & Model 1 & Model 2 \\
\hline Constant & -0.3722 & -0.4439 & -0.9171 & -0.9599 \\
block & 1.0619 & 1.6648 & $\mathbf{1 . 9 8 4 8}^{\mathbf{c}}$ & $\mathbf{2 . 2 2 0 9}^{\mathbf{c}}$ \\
block*crisis & - & $-2.2404^{\mathrm{b}}$ & - & -0.5863 \\
Fisher/wald & $0.55(0.45)$ & $5.36(0.06)$ & $3.50(0.06)$ & $4.16(0.12)$ \\
$\mathrm{R}^{2}$ & 0.0469 & 0.1929 & 0.2089 & 0.2404 \\
$\mathrm{~N}$ & 72 & 72 & 120 & 120 \\
Chi2(prob) & $0.9(0.636)$ & $0.52(0.902)$ & $0.11(0.94)$ & $0.07(0.99)$ \\
\hline
\end{tabular}

a, b, c coefficients are significant at the 1,5 , and 10 percent respectively.

Zingales (1995) argues that the IPO is an operation that maximizes the wealth of the old shareholders. As a result, society is undergoing transformations in control and power structure. The results obtained indicate that capital concentration is associated with positive abnormal returns over a 5-year period. Fims whose capital is concentrated are increasingly under-valued over a long period after the IPO.

\subsection{Performance Motivation}

Table 4. Performance motivation

\begin{tabular}{lcccc}
\hline & \multicolumn{2}{c}{ The first 3 years after IPO } & \multicolumn{2}{c}{ The first 5 years after IPO } \\
\cline { 2 - 5 } & Model 1 & Model 2 & Model 1 & Model 2 \\
\hline Constant & 0.1990 & 0.2116 & 0.1582 & 0.15561 \\
ROE & 0.0124 & 0.6505 & 0.0420 & 0.0416 \\
ROE*crisis & - & -2.7578 & - & 0.0570 \\
Fisher/wald & $0.00(0.99)$ & $0.73(0.69)$ & $0.07(0.79)$ & $0.07(0.96)$ \\
$\mathrm{R}^{2}$ & 0.0022 & 0.0222 & 0.0019 & 0.0027 \\
$\mathrm{~N}$ & 72 & 72 & 120 & 120 \\
Chi2(pob>chi2) & $0.16(0.92)$ & $0.07(0.99)$ & $0.00(0.99)$ & $0.12(0.98)$ \\
\hline
\end{tabular}

The relationship between performance and the IPO is ambiguous. On the one hand, high cash flows make the company more independent of external investors, ease its financing constraints, and should therefore reduce the likelihood of an IPO. On the other hand, high profitability could represent a credible signal of the quality of a company, thus making it possible to overcome the adverse selection (Diamand, 1991). Our results show that our Tunisian companies do not observe the motivation of the search for a better performance.

\subsection{Liquidity Motivation}

Table 5. Liquidity motivation

\begin{tabular}{lcccc}
\hline & \multicolumn{2}{c}{ The first 3 years after IPO } & \multicolumn{2}{c}{ The first 5 years after IPO } \\
\cline { 2 - 5 } & Model 1 & Model 2 & Model 1 & Model 2 \\
\hline Constant & 0.2090 & 0.2564 & 0.1674 & 0.1619 \\
liquid & -0.0024 & 0.0509 & -0.0023 & 0.0064 \\
liquid*crisis & - & $-\mathbf{0 . 2 7 0 8}^{\mathbf{b}}$ & - & -0.0242 \\
Fisher/wald & $0.00(0.971)$ & $5.5(0.06)$ & $0.00(0.95)$ & $0.10(0.95)$ \\
$\mathrm{R}^{2}$ & 0.0038 & 0.1897 & 0.0094 & 0.1125 \\
$\mathrm{~N}$ & 72 & 72 & 120 & 120 \\
Chi2(pob>chi2) & $0.29(0.86)$ & $0.56(0.90)$ & $0.26(0.87)$ & $2.58(0.46)$ \\
\hline
\end{tabular}

The decision to go public affects the liquidity of listed shares. The liquidity of the securities for the former shareholders may be the main motivation to enter the stock market. Mello and Parsons (1998) shows that the IPO is a vehicle that will create a liquid secondary market for the firm's shares in order to allow investors to improve the liquidity of their portfolios. Our results show that liquidity is associated with negative returns. This result confirms the idea that the IPO improves the under-valuation of firms in the short term. 


\subsection{Earning Management Motivation}

Table 6. Earning management motivation

\begin{tabular}{lcccc}
\hline & \multicolumn{2}{c}{ The first 3 years after IPO } & \multicolumn{2}{c}{ The first 5 years after IPO } \\
\cline { 2 - 5 } & Model 1 & Model 2 & Model 1 & Model 2 \\
\hline Constant & 0.2267 & 0.3346 & 0.1485 & 0.1682 \\
D.Acc & 0.9304 & 1.7786 & -0.1491 & -0.0648 \\
D.Acc*crisis & - & $-\mathbf{1 8 . 9 5 5}^{\mathbf{b}}$ & - & $\mathbf{- 7 . 8 9 2 1 ^ { \mathbf { c } }}$ \\
Fisher/wald & $0.26(0.60)$ & $4.89(0.08)$ & $0.12(0.72)$ & $3.67(0.15)$ \\
$\mathrm{R}^{2}$ & 0.0047 & 0.17 & 0.0094 & 0.1093 \\
$\mathrm{~N}$ & 72 & 72 & 120 & 120 \\
Chi2(prob>chi2) & $0.19(0.90)$ & $0.83(0.84)$ & $0.04(0.98)$ & $0.03(0.99)$ \\
\hline
\end{tabular}

Previous studies show that firms with a high level of disclosure are more likely to go public. Dechow and Skinner (2000) point out that public share offerings provide a direct incentive to manage results as leaders can adjust published earnings upwards. Other studies have shown that companies that make initial issues actually manipulate their financial statements. The empirical results show that earning management motivation is associated with abnormal negative returns as well over 3 years and 5 years after the IPO. This result remains valid in times of financial crisis.

\section{Conclusion}

This paper aims to examine the factors that push companies to open its capital to the public. In particular, it examines the impact of a number of factors to explain the under valuation of stock market introduction, particularly performance, debt, liquidity and ownership structure. Our results demonstrate that large companies generally have better access to the capital needed to finance their investments. (Ibbotson et al., 1994; Carter et al., 1998). The size of the firm is associated with negative abnormal returns after the IPO over a period of 5 years. In addition, our results show that companies newly introduced on the stock market ( 3 years) and which are indebted realize negative abnormal returns. This result confirms the hypothesis that indebtedness accentuates the problem of overvaluation observed after the IPO. Pagans et al. (1998) point out that access to a source of financing other than banks or venture capital is the main advantage of the IPO. Basile (1988) and Pagans et al. (1998) also believe that access to capital markets can decrease the cost of credit as a result of bargaining power with banks.

The relationship between performance and the IPO is ambiguous: high cash flows make the company more independent of external investors, ease its financing constraints, and should therefore reduce the likelihood of an IPO. In addition, high profitability could represent a credible signal of the quality of a company, thus making it possible to overcome the adverse selection (Diamand, 1991). The IPO affects the liquidity of listed shares. This result confirms the idea that the IPO improves the under-valuation of firms in the short term. The empirical results show that earning management motivation is associated with abnormal negative returns as well over 3 years and 5 years after the IPO. This result remains valid in times of financial crisis.

\section{References}

Basile, I. (1988). Gli intermediari creditizi e la quotazione di Borsa. L'ammissione alla quotazione di Borsa. In M. Cattaneo et al. (Eds.), analisi interdisciplinare. Vita e Pensiero: Milano.

Boehmer, E., \& Ljungqvist, A. (2004). On the decision to go public: Evidence from privately-held firms. Working Paper (New York University).

Brau, J. C., \& Fawcett, S. E. (2006). Initial public Offerings: An Analysis of Theory and Practice. Journal of Finance, 61(1), 399-436. https://doi.org/10.1111/j.1540-6261.2006.00840.x

Carter, R., Dark, F., \& Singh, A. (1998). Underwriter reputation, initial returns, and the long-run performance of IPO stocks. Journal of Finance, 53, 285-311. https://doi.org/10.1111/0022-1082.104624

Chemmanur, T. J., \& Fulghieri, P. (1999). A Theory of the going-public decision. The Review of Financial Studies, 12, 249-279. https://doi.org/10.1093/rfs/12.2.249

Chen, Z., Choi, J. J., \& Jiang, C. (2007). Corruption in State Owned Firms: Evidence from China's IPOs. Temple University working paper.

Chen, G., Firth, M., \& Kim, J. B. (2004). IPO Underpricing in China's New Stock Markets. Journal of Multinational Financial Management, 14(3), 283-302. https://doi.org/10.1016/j.mulfin.2003.07.007

Dechow, P., \& Skinner, D. (2000). Earnings management: Reconciling the views of accounting academics, 
practitioners, and regulators. Accounting Horizons, 14, 235-250. https://doi.org/10.2308/acch.2000.14.2.235

Diamond, D. W. (1991). Monitoring and reputation: The choice between bank loans and directly placed debt. Journal of Political Economy, 99, 689-721. https://doi.org/10.1086/261775

Ibbotson, R. G., Sindelar, J., \& Ritter, J. (1994). The market's problems with the pricing of initial public offerings. Journal of Applied Corporate Finance, 7, 66-74. https://doi.org/10.1111/j.1745-6622.1994.tb00395.x

Jog, V. M., \& Riding, A. L. (1987). Underpricing in Canadian IPOs. Financial Analysts Journal, NovemberDecember, 48-54. https://doi.org/10.2469/faj.v43.n6.48

Jog, V. M., \& Srivastava, A. (1994). Underpricing of Canadian initial public offerings 1971-1992: An update. Fineco, 4(1), 81-89.

Kryzanowski, L., Lazrak, S., \& Rakita, I. (2005). The behavior of prices, trades and spreads for Canadian IPOs. Multinational Finance Journal, 9(3/4), 215-236. https://doi.org/10.17578/9-3/4-4

Loughran, T., Ritter, J. R., \& Rydqvist, K. (2013). Initial Public Offerings International Insights. Pacific-Basin Finance Journal, 2, 165-199. http://dx.doi.org/10.1016/0927-538X(94)90016-7

Lowry, M., Officer, M. G., \& Schwert, W. (2010). The variability of IPO initial returns. Journal of Finance, 1(6), 399-436. https://doi.org/10.1111/j.1540-6261.2009.01540.x

Maksimovic, V., \& Pichler, P. (2001). Technological innovation and initial public offerings. The Review Of Financial Studies, 14, 459-494. https://doi.org/10.1093/rfs/14.2.459

Mello, A. S., \& Parsons, J. E. (1998). Going public and the ownership structure of the firm. Journal of Financial Economics, 49(1), 70-109. https://doi.org/10.1016/S0304-405X(98)00018-X

Mikkelson, W., Partch, M., \& Shah, K. (1997). Ownership and operating performance of companies that go public. Journal of Financial Economics, 44, 281-307. https://doi.org/10.1016/S0304-405X(97)00006-8

Modigliani, F., \& Miller, M. H. (1963). Corporate Income Taxes and the Cost of Capital A Correction. American Economic Review, 53, 433-443.

Myers, S., \& Majluf, N. (1984). Corporate financing and investment decisions when firms have information that investors do not have. Journal of Financial Economics, 13, 187-221. https://doi.org/10.1016/0304-405X(84)90023-0

Pagano, M., Panetta, F., \& Zingales, L. (1998). Why Do Companies Go Public? An Empirical Analysis. Journal of Finance, 53, 27-64. https://doi.org/10.1111/0022-1082.25448

Ritter, J. (1984). Signalling and the valuation of unseasoned new issues: A comment. Journal of Finance, 39, 1231-1237. https://doi.org/10.1111/j.1540-6261.1984.tb03907.x

Ritter, J. (1984). The hot issue' market of 1980. Journal of Business, 57(2), 215-240. https://doi.org/10.1086/296260

Ritter, J., \& Beatty, R. (1986). Investment Banking, Reputation, and the Underpricing of Initial Public Offerings. Journal of Financial Economics, 15, 213-232. https://doi.org/10.1016/0304-405X(86)90055-3

Ritter, J. (1998). Initial Public Offering. Contemporary Finance Digest. https://doi.org/10.1111/j.1745-6622.1988.tb00164.x

Rock, K. (1986). Why new issues are underpriced. Journal of Financial Economics, 15, 187-212. https://doi.org/10.1016/0304-405X(86)90054-1

Rydqvist, K., \& Högholm, K. (1995). Going public in the 1980s: Evidence from Sweden. European Financial Management, 1, 287-315. https://doi.org/10.1111/j.1468-036X.1995.tb00021.x

Scott, J. H. (1976). A Theory of Optimal Capital Structure. The Bell Journal of Economics (Spring 1976). https://doi.org/10.2307/3003189

Sohail, M., \& Nasr, M. (2007). Performance of Initial Public Offerings in Pakistan. International Review of Business Research Papers, 3(2), 420-441.

\section{Copyrights}

Copyright for this article is retained by the author(s), with first publication rights granted to the journal.

This is an open-access article distributed under the terms and conditions of the Creative Commons Attribution license (http://creativecommons.org/licenses/by/4.0/). 